\title{
Remote Sensing for Grassland Management in the Arid Southwest
}

\author{
Robert C. Marsett, ${ }^{1}$ Jiaguo Qi, ${ }^{2}$ Philip Heilman, ${ }^{3}$ \\ Sharon H. Biedenbender, ${ }^{4}$ M. Carolyn Watson, ${ }^{5}$ Saud Amer, ${ }^{6}$ \\ Mark Weltz, ${ }^{7}$ David Goodrich, ${ }^{8}$ and Roseann Marsett ${ }^{9}$ \\ Authors are ${ }^{1}$ Principal, RANGES LLC, Tucson, AZ 85749; ${ }^{2}$ Associate Professor, Department of Geography, \\ Michigan State University, East Lansing, MI 48824; ${ }^{3}$ Research Biologist, USDA-ARS Southwest Watershed Research Center, \\ Tucson, AZ 85719; ${ }^{4}$ Ecologist, USDA Forest Service, Sierra Vista, AZ 85615; ${ }^{5}$ Sensors and Equipment Technician, \\ Arizona Meteorological Network, Tucson, AZ 85721; ${ }^{6}$ Physical Scientist, Technical Advisor, USGS, Washington, DC 20005; \\ ${ }^{7}$ National Program Leader, USDA-ARS, Beltsville, MD 20705; ${ }^{8}$ Research Hydraulic Engineer, USDA-ARS Southwest Watershed \\ Research Center Tucson, AZ 85719; and ${ }^{9}$ Director, Geospatial Production Division, General Dynamics, Tucson, AZ 85711.
}

\begin{abstract}
We surveyed a group of rangeland managers in the Southwest about vegetation monitoring needs on grassland. Based on their responses, the objective of the RANGES (Rangeland Analysis Utilizing Geospatial Information Science) project was defined to be the accurate conversion of remotely sensed data (satellite imagery) to quantitative estimates of total (green and senescent) standing cover and biomass on grasslands and semidesert grasslands. Although remote sensing has been used to estimate green vegetation cover, in arid grasslands herbaceous vegetation is senescent much of the year and is not detected by current remote sensing techniques. We developed a ground truth protocol compatible with both range management requirements and Landsat's $30 \mathrm{~m}$ resolution imagery. The resulting ground-truth data were then used to develop image processing algorithms that quantified total herbaceous vegetation cover, height, and biomass. Cover was calculated based on a newly developed Soil Adjusted Total Vegetation Index (SATVI), and height and biomass were estimated based on reflectance in the near infrared (NIR) band. Comparison of the remotely sensed estimates with independent ground measurements produced $r^{2}$ values of $0.80,0.85$, and 0.77 and Nash Sutcliffe values of $0.78,0.70$, and 0.77 for the cover, plant height, and biomass, respectively. The approach for estimating plant height and biomass did not work for sites where forbs comprised more than $30 \%$ of total vegetative cover. The ground reconnaissance protocol and image processing techniques together offer land managers accurate and timely methods for monitoring extensive grasslands. The time-consuming requirement to collect concurrent data in the field for each image implies a need to share the high fixed costs of processing an image across multiple users to reduce the costs for individual rangeland managers.
\end{abstract}

\section{Resumen}

Entrevistamos a un grupo de manejadores de pastizales del sudoeste con respecto a las necesidades de monitoreo de la vegetación del pastizal. En base a sus respuestas, el objetivo del proyecto RANGES (Rangeland Analisis Utilizing Geospatial Information Science) fue definido para ser una conversión certera de datos de sensores remotos (imágenes de satélite) a estimaciones cuantitativas de la cobertura total (verde y senescente) y la biomasa de los pastizales y pastizales semiáridos. Mientras que los sensores remotos han sido utilizados para estimar la cobertura de la vegetación verde, en los pastizales semiáridos, la vegetación herbácea esta senescente gran parte del año y no es detectada por la técnicas actuales de sensores remotos. Desarrollamos un protocolo terrestre compatible tanto con los requerimientos de manejo de pastizales como los de imágenes de 30 metros de resolución del Landsat. Los datos terrestres verdaderos resultantes fueron usados para desarrollar los algoritmos de procesamiento de imágenes que cuantificaron la cobertura total, altura, y biomasa de la vegetación herbácea. La cobertura fue calculada en base a un Indice de Vegetación Total Ajustado por Suelo (SATVI), recientemente desarrollado, mientras que la altura y la biomasa fueron estimadas en base a la reflexión de la banda cercana al infrarrojo (NIR). La comparación de las estimaciones de los sensores remotos con las mediciones independientes de campo produjeron valores de $r^{2}$ de 0.80, 0.85 y 0.77 y valores de Nash Sutcliffe de 0.78, 0.70, y 0.77 para la cobertura, altura de planta, y biomasa respectivamente. Esta forma de estimar la altura de planta y biomasa no funcionó para sitios donde las hierbas aportaron más del $30 \%$ de la cobertura vegetal total. El uso conjunto del protocolo de reconocimiento terrestre y las técnicas de procesamiento de imágenes ofrecen a los manejadores de pastizales métodos certeros y eficientes en tiempo para monitorear pastizales extensivos. Los requerimientos de tiempo para colectar en campo los datos concurrentes para cada imagen implica una necesidad de compartir entre los usuarios múltiples los altos costos fijos del procesamiento de cada imagen para reducir los costos a nivel de manejador de pastizal individual.

Key Words: remote sensing, biomass, height, cover

This research was performed at the USDA-ARS Southwest Watershed Research Center and Michigan State University using funding from NASA (98-0ES-09). Partial support was also provided by NASA grants (NNG05GD49G and NS-7734) at Michigan State University.

Mention of any trade name or proprietary product does not constitute a guarantee or warranty by the authors or any governmental agency, nor does it imply the approval of these products to the exclusion of others.

Correspondence: Robert C. Marsett, RANGES LLC, 5031 N. Calle Tobosa, Tucson, AZ 85749. Email: rmarsett@comcast.net

Manuscript received 19 November 2005; manuscript accepted 21 May 2006. 


\section{INTRODUCTION}

Rangelands occupy over half of the land area of the United States and represent a major source of food production (Holechek et al. 1989). Rangelands also play a vital environmental role in water quality, soil conservation, wildlife habitat, and recreation (National Research Council 1994). Maximizing rangeland production while preventing land degradation is a challenging task for range managers for many reasons, among which are: 1) rangelands are vast, and spatial information is difficult to obtain in a timely manner; 2) variable annual weather patterns make the prediction of vegetation production difficult; and 3) traditional field surveys of rangeland condition and production are labor intensive, time consuming, and expensive (Pickup et al. 1994; Reeves et al. 2001; Tueller 2001).

In the past, remote sensing data have not been a commonly used operational tool for rangeland managers (Hunt et al. 2003). One reason for this lack of success has been the inability to quantify the rangeland vegetation regardless of season or condition. Remote sensing has been useful primarily in detecting green vegetation, but senescent or cured vegetation was missed. Cured grasses are a critical component of the western rangeland systems because they provide the bulk of the winter feed for wildlife and livestock as well as cover for ground nesting birds and other animals. Galt et al. (1982) reported in a study of fistulated steers that grass constituted $86 \%$ of a year's diet on the Santa Rita Experimental Range in southeastern Arizona. These senescent grasses are also an important component in intercepting rainfall to reduce erosion and as a source of fine fuels for range and forest fires. The objective was to develop geospatial information products that characterize grassland vegetation in the Southwest, over large areas, capable of application throughout the year. This tool must be accurate, timely, cost effective, and user friendly to be of value to rangeland managers.

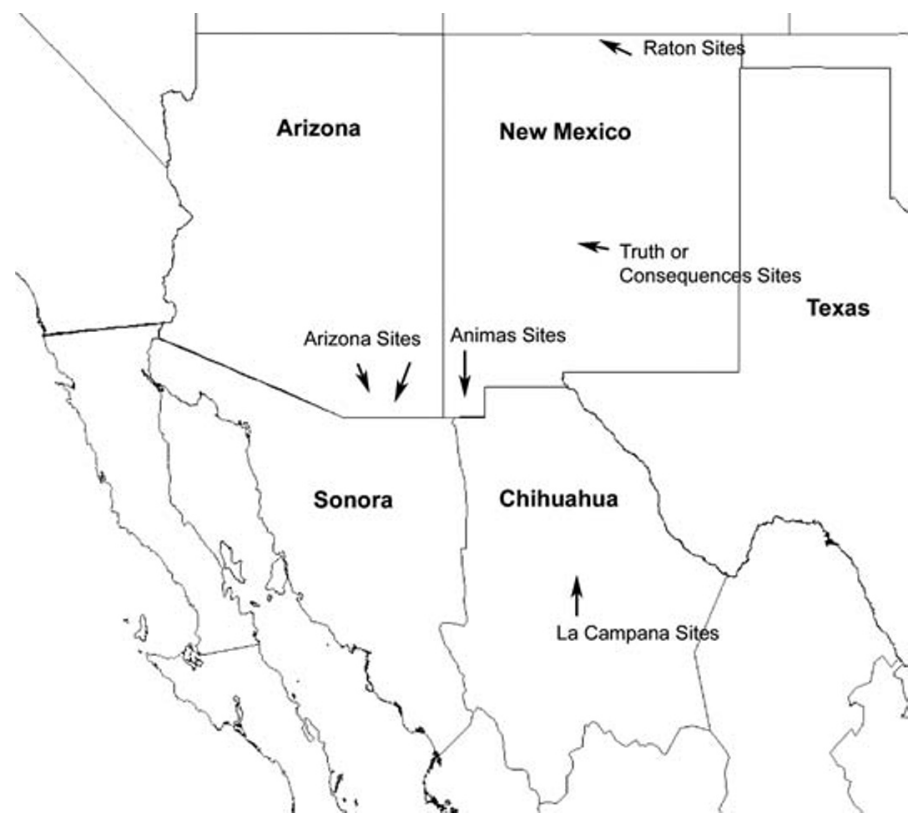

Figure 1. Field sites ranged from northern New Mexico to central Chihuahua and west to southeastern Arizona.
To achieve this objective it was necessary to develop a ground truth protocol that could support remote sensing, as well as to develop imagery processing algorithms to quantify both senescent and green vegetation, and produce maps of the remote sensing derived information that were useful to the end users. This paper describes the progress that RANGES (Rangeland Analysis Utilizing Geospatial Information Science), a research project funded by NASA, made toward achieving these goals.

\section{MATERIALS AND METHODS}

\section{Rangeland Management Requirements}

Eighteen organizations and individuals with responsibility for managing southwestern rangelands were questioned to determine if there was a need for large area monitoring tools, and if so, what characteristics would make such tools useful. The responses were compiled and the results presented at a stakeholders meeting along with the proposed solution, again asking for further input. The participants believed that maps showing the quantity of vegetation across the landscape would help them monitor large areas of rangeland. Grassland was the highest priority. The consensus was that the information must be accurate, timely, and easy to use. The expressed preference for timing was first for the postsummer growing season and second for presummer growing season. The reasons for these times were that a postgrowing season coverage would tell the user how much forage was available for the coming winter, whereas the pregrowing season coverage would act as a check on how much forage was used over the winter season.

\section{Field Data Acquisition}

The field data acquisition began with the selection of ground reconnaissance sites. Field study sites were $90 \times 150 \mathrm{~m}$ to accommodate fifteen 30-m Landsat pixels. This assured at least 3 pixels were uncorrupted by edge effects. Sites were chosen to maximize within-site homogeneity and to represent betweensite heterogeneity in both vegetation and land use.

Selected ground sites representing primarily grassland biotic communities are located from the Colorado and New Mexico border in the north to central Chihuahua, Mexico, in the south and southeastern Arizona in the west (Fig. 1). These sites represent biotic communities across North America including semiarid desert grasslands of central Chihuahua and the Jornada del Muerto in New Mexico, mixed grass grassland of southeastern Arizona and southwestern New Mexico, Rocky Mountain subalpine parks of the Sangre de Cristo mountains in northern New Mexico, short grass prairie of northern New Mexico, Ponderosa pine (Pinus ponderosa P. and C. Lawson) open park woodlands of northern New Mexico, and Madrean woodland of southeastern Arizona. Low elevation sites dominated by brush were avoided, as were woodlands found at higher elevations. There are a total of 35 sites. Each of the sites is located on either public land or private land managed by various RANGES stakeholders. Study sites included sites that were grazed and ungrazed, native and nonnative vegetation, as well as riparian sites dominated by Sacaton (Sporobolus spp.). The major characteristics of each site can be seen in Table 1 . 
Table 1. RANGES field sites include a variety of grassland dominated vegetation types with diverse management systems.

\begin{tabular}{|c|c|c|c|c|c|c|c|}
\hline Site & Vegetation type $^{1}$ & $\begin{array}{c}\text { Dominant } \\
\text { perennials }^{2}\end{array}$ & Land use & $\begin{array}{c}\text { Precipitation } \\
\mathrm{mm} \cdot \mathrm{yr}^{-1}\end{array}$ & $\begin{array}{c}\text { Elevation } \\
\mathrm{m}\end{array}$ & $\begin{array}{c}\text { Slope } \\
\%\end{array}$ & Soil ${ }^{3}$ \\
\hline \multicolumn{8}{|l|}{ Arizona } \\
\hline Audubon Native & Plains Grassland & $a, b$ & $\begin{array}{l}\text { Ungrazed by livestock since 1968; } \\
\text { burned in Spring of } 2002\end{array}$ & 430 & 1476 & 3 & White House gravelly loam \\
\hline Audubon Lehmann & $\begin{array}{l}\text { Lehmann Lovegrass } \\
\text { Monoculture }\end{array}$ & $c, d$ & $\begin{array}{l}\text { Ungrazed by livestock since 1968; } \\
\text { burned in Spring of } 2002\end{array}$ & 430 & 1466 & 3 & White House gravelly loam \\
\hline Audubon Fenceline & Plains Grassland & $a, b$ & $\begin{array}{l}\text { Ungrazed by livestock since 1968; } \\
\text { burned in Spring of } 2002\end{array}$ & 430 & 1485 & 3 & White House gravelly loam \\
\hline Audubon Sacaton & Sacaton Bottom & $e, f$ & $\begin{array}{l}\text { Ungrazed by livestock since 1968; } \\
\text { burned in Spring of } 2002\end{array}$ & 430 & 1445 & 1 & Pima silty clay loam \\
\hline Elgin Fenceline & Plains Grassland & $\mathrm{a}, \mathrm{g}$ & $\begin{array}{l}\text { High intensity short duration } \\
\text { grazing (livestock) }\end{array}$ & 430 & 1486 & 3 & White House gravelly loam \\
\hline Elgin Native & Plains Grassland & $\mathrm{a}, \mathrm{h}$ & $\begin{array}{l}\text { Moderate intensity rotation } \\
\text { grazing (livestock) }\end{array}$ & 400 & 1480 & 3 & White House gravelly loam \\
\hline Empire Exclosure & Plains Grassland & $\mathrm{a}, \mathrm{I}$ & Ungrazed by livestock & 375 & 1481 & 5 & Elgin-Sasabe Complex \\
\hline Empire $\mathrm{E}$ of Exclosure & Plains Grassland & $\mathrm{a}, \mathrm{l}$ & $\begin{array}{l}\text { Moderate intensity rotation } \\
\text { grazing (livestock) }\end{array}$ & 375 & 1479 & 4 & Elgin-Sasabe Complex \\
\hline Empire Mole & Semidesert Grassland & $c, j$ & $\begin{array}{l}\text { Moderate intensity rotation } \\
\text { grazing (livestock) }\end{array}$ & 350 & 1390 & 3 & Elgin-Sasabe Complex \\
\hline Empire $\mathrm{N}$ of Karen & Plains Grassland & $\mathrm{a}, \mathrm{g}$ & $\begin{array}{l}\text { Moderate intensity rotation } \\
\text { grazing (livestock) }\end{array}$ & 350 & 1390 & 3 & Elgin-Sasabe Complex \\
\hline Empire Lehmann & Plains Grassland & c & $\begin{array}{l}\text { Moderate intensity rotation } \\
\text { grazing (livestock) }\end{array}$ & 350 & 1400 & 3 & Elgin-Sasabe Complex \\
\hline Empire Sacaton 1-3 & Sacaton Bottom & $f$ & $\begin{array}{l}\text { Moderate intensity rotation } \\
\text { grazing (livestock) }\end{array}$ & 350 & 1400 & 1 & Pima silty clay loam \\
\hline Empire Shipping & Plains Grassland & $\mathrm{a}, \mathrm{g}$ & $\begin{array}{l}\text { Moderate intensity rotation } \\
\text { grazing (livestock) }\end{array}$ & 350 & 1400 & 3 & Elgin-Sasabe Complex \\
\hline Empire Hilton & Plains Grassland & $\mathrm{a}, \mathrm{g}$ & $\begin{array}{l}\text { Moderate intensity rotation } \\
\text { grazing (livestock) }\end{array}$ & 400 & 1480 & 3 & Elgin-Sasabe Complex \\
\hline Empire South & Plains Grassland & a, c & $\begin{array}{l}\text { Moderate intensity rotation } \\
\text { grazing (livestock) }\end{array}$ & 375 & 1415 & 5 & Elgin-Sasabe Complex \\
\hline Ft Huachuca Lehmann & Plains Grassland & c & Ungrazed by livestock & 375 & 1450 & 3 & Gardencan-Lanque Complex \\
\hline Ft Huachuca Native & Plains Grassland & $\mathrm{k}, \mathrm{l}$ & Ungrazed by livestock & 430 & 1551 & 3 & Gardencan-Lanque Complex \\
\hline Fort Huachuca Oak & Madrean Woodland & $\mathrm{m}, \mathrm{n}, \mathrm{0}, \mathrm{l}$ & Ungrazed by livestock & 500 & 1646 & 30 & Budlamp-Woodcutter Complex \\
\hline Walnut Gulch North & Semidesert Grassland & $g, p, i$ & $\begin{array}{l}\text { Moderate intensity rotation } \\
\text { grazing (livestock) }\end{array}$ & 350 & 1525 & 34 & $\begin{array}{l}\text { Stronghold-Elgin-McAllister } \\
\text { Complex }\end{array}$ \\
\hline Walnut Gulch South & Semidesert Grassland & $q, I, r, s$ & $\begin{array}{l}\text { Moderate intensity rotation } \\
\text { grazing (livestock) }\end{array}$ & 350 & 1525 & 12 & $\begin{array}{l}\text { Stronghold-Elgin-McAllister } \\
\text { Complex }\end{array}$ \\
\hline Brookline Treated & Semidesert Grassland & $\mathrm{j}, \mathrm{t}, \mathrm{u}$ & $\begin{array}{l}\text { Moderate intensity rotation } \\
\text { grazing (livestock) }\end{array}$ & 325 & 1290 & 3 & Contention-UGYP Complex \\
\hline Brookline Untreated & Semidesert Grassland & $\mathrm{j}, \mathrm{t}, \mathrm{u}$ & $\begin{array}{l}\text { Moderate intensity rotation } \\
\text { grazing (livestock) }\end{array}$ & 325 & 1290 & 3 & Contention-UGYP Complex \\
\hline Brookline Shrub Low & Semidesert Grassland & $\mathrm{j}, \mathrm{t}, \mathrm{u}$ & $\begin{array}{l}\text { Moderate intensity rotation } \\
\text { grazing (livestock) }\end{array}$ & 325 & 1290 & 3 & Contention-UGYP Complex \\
\hline \multicolumn{8}{|l|}{ New Mexico } \\
\hline Animas BG Flats & Plains Grassland & $\mathrm{a}, \mathrm{r}, \mathrm{v}$ & $\begin{array}{l}\text { Moderate intensity rotation } \\
\text { grazing (livestock) }\end{array}$ & 350 & 1646 & 3 & Forest gravelly loam \\
\hline Animas Cow Camp & Plains Grassland & $w, x$ & $\begin{array}{l}\text { Moderate intensity rotation } \\
\text { grazing (livestock) }\end{array}$ & 350 & 1646 & 3 & Forest gravelly loam \\
\hline Animas Mac Flats & Plains Grassland & $\mathrm{I}, \mathrm{a}$ & $\begin{array}{l}\text { Moderate intensity rotation } \\
\text { grazing (livestock) Burned } \\
\text { Spring } 2001\end{array}$ & 350 & 1670 & 3 & Forest gravelly loam \\
\hline $\mathrm{T}$ or $\mathrm{C}$ Black Grama & Semidesert Grassland & $\mathrm{r}, \mathrm{y}$ & $\begin{array}{l}\text { Low intensity rotation } \\
\text { grazing (buffalo) }\end{array}$ & 200 & 1372 & 5 & Simona loamy fine sand \\
\hline
\end{tabular}


Table 1. Continued.

\begin{tabular}{|c|c|c|c|c|c|c|c|}
\hline Site & Vegetation type $^{1}$ & $\begin{array}{c}\text { Dominant } \\
\text { perennials }^{2}\end{array}$ & Land use & $\begin{array}{c}\text { Precipitation } \\
\mathrm{mm} \cdot \mathrm{yr}^{-1}\end{array}$ & $\begin{array}{c}\text { Elevation } \\
\mathrm{m}\end{array}$ & $\begin{array}{c}\text { Slope } \\
\%\end{array}$ & Soill $^{3}$ \\
\hline $\mathrm{T}$ or C Sacaton & Sacaton Flat & $\mathrm{z}, 1$ & $\begin{array}{l}\text { Low intensity rotation } \\
\text { grazing (buffalo) }\end{array}$ & 200 & 1372 & 2 & Holloman fine sandy loam \\
\hline Raton Prairie & Shortgrass Prairie & a, 2 & $\begin{array}{l}\text { Moderate intensity rotation } \\
\text { grazing (buffalo) }\end{array}$ & 350 & 1676 & 2 & Manzano Association \\
\hline Raton Subalpine & Smooth Brome Monoculture & 3 & Low intensity grazing (elk) & 500 & 2286 & 2 & $\begin{array}{l}\text { Deacon-La Vrier-Manzano } \\
\text { Association }\end{array}$ \\
\hline Raton Ponderosa & Ponderosa Woodland & a, $4,5,6$ & Low intensity grazing (elk) & 500 & 2330 & 2 & $\begin{array}{l}\text { Dargol-Stout-Varmer } \\
\text { Association }\end{array}$ \\
\hline \multicolumn{8}{|l|}{ Mexico } \\
\hline La Campana 1-2 & Semidesert Grassland & $c, r$ & $\begin{array}{l}\text { Moderate intensity rotation } \\
\text { grazing (livestock) }\end{array}$ & 350 & 1580 & 3 & Similar to Elgin ${ }^{4}$ \\
\hline
\end{tabular}

${ }^{1}$ Vegetation types are from Brown and Lowe (1994) except for those indicating dominance by a single species.

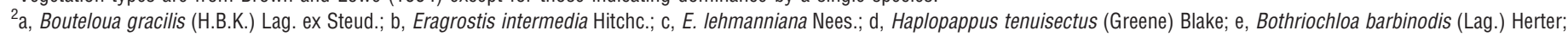
f, Sporobolus wrightii Munro ex Scribn; g, B. hirsuta Lag.; h, Lycurus setosus (Nutt.) C. G. Reeder; i, B. curtipendula (Michx.) Torr; j, Aristida spp.; k, Heteropogon contortus (L.) Beauv.;

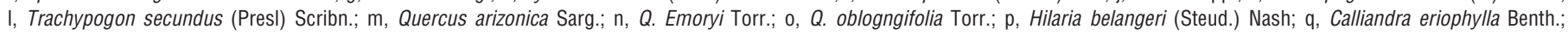
r, B. eriopoda (Torr.) Torr.; s, Hilaria mutica (Buckl.) Benth; t, Larrea tridentata (DC) Coville; u, Muhlenbergia porteri Scribn.; v, Panicum obtusum H.B.K.; w, Lepidium thurberi Woot.; X, B. aristidoides (H.B.K) Grisb.; y, Yucca elata Engelm.; z, Sporobolus airoides Torr.; 1, H. heterophyllus (Gray) Blake; 2, Opuntia spp.; 3, Bromus inermis Leyss; 4, Pinus ponderosa Lawson; 5, M. Montana (Nutt.) Hitchc.; 6 Danthonia parryi Scribn.

${ }^{3}$ Soils information is from USDA-NRCS (2005).

${ }^{4}$ Personal communication, Don Breckenfeld, 2002.

\section{Ground Reconnaissance Protocol}

The ground reconnaissance protocol has to accurately measure those ground conditions that the satellite image is capable of observing. After comparing methods, the following measurements were adopted for each site: line intercept canopy cover by species, line intercept plant height by life form, line intercept ground cover and color, comparative yield for biomass, and relative green vs. brown biomass. Vegetation data collection methods evaluated included clipped, oven-dried and weighed biomass by lifeform (grass, forb, shrub) within 1- $\mathrm{m}^{2}$ quadrats; pin-frame canopy cover, ground cover, and plant height by color (green vs. brown); line intercept canopy cover by species; height by lifeform and ground cover; leaf area using a canopy analyzer; and biomass estimates utilizing the comparative yield method. Collections were made during the winter/spring period from January to early June and at the end of the summer growing season from late August to November (2000-2005).

Comparative Yield Biomass Estimates. Estimating standing biomass or forage was one of the primary goals. Initially, clipping biomass within $1-\mathrm{m}^{2}$ quadrats was evaluated, but calculations of minimum sample sizes revealed that 50-100 quadrats would be necessary to capture the variability on these sites. Calculations of sample size were performed using $521-\mathrm{m}^{2}$ quadrats clipped at the Audubon Native site during the winter/ spring period in 2000 using Student's $t$ statistics. Total biomass required 77 clipped samples to achieve $90 \%$ confidence plus or minus $10 \%$ of the mean. Grass biomass alone required 46 clipped samples for the same confidence level. Clipping was too time-consuming for practical use, so the comparative yield method (Bureau of Land Management 1996; Despain and Smith 1997) for estimating standing biomass was tested during the winter/spring 2000 period on three sites and then used for all subsequent sites. One hundred $1-\mathrm{m}^{2}$ quadrats were estimated with the comparative yield method for each site, and a subset of quadrats for a site was selected for clipping and weighing.
The comparative yield method is a well-documented and wellaccepted estimation technique that combines the speed and convenience of an ocular estimation method with the accuracy and repeatability of (limited) clipping methods. Quadrats were sampled along three $150-\mathrm{m}$ baselines, each of which theoretically passed through 5 Landsat Thematic Mapper pixels $(30 \times 30 \mathrm{~m})$.

A very high biomass, ungrazed native grass site was selected as a comparative yield calibration site to verify that ocular estimates had a good relationship with actual clipped biomass. During the winter/spring 2000 sampling period, 55 quadrats were clipped for which comparative yield biomass estimates were also made. There was a good relationship for 2 observers between the clipped biomass and the comparative yield estimates (Fig. 2). The mean clipped biomass from the 55 quadrats was $1771 \mathrm{~kg} \cdot \mathrm{ha}^{-1}$, with a standard deviation of $652 \mathrm{~kg} \cdot \mathrm{ha}^{-1}$. Using the comparative yield method, observer 1 's ranking of the 55 quadrats yielded an estimate of 1644 $\mathrm{kg} \cdot \mathrm{ha}^{-1}$, an underestimation of $127 \mathrm{~kg} \cdot \mathrm{ha}^{-1}$ or $7 \%$ (Fig. 2a). Observer 2's estimate was $1618 \mathrm{~kg} \cdot \mathrm{ha}^{-1}$, an underestimation of $153 \mathrm{~kg} \cdot \mathrm{ha}^{-1}$ or $9 \%$ (Fig. 2b). The correlations between clipped and estimated biomass for the observers were 0.91 and 0.90 , respectively. Paired $t$ tests indicated a significant difference in means between clipped weights and both observers $(P=0.002$ and $P=0.001$ for observers 1 and 2 , both with $\mathrm{df}=54)$. There was no significant difference between the observers $(P=0.34)$. Because the comparative yield method is well established and there was close agreement between the methods, we were satisfied that the comparative yield method would provide adequate estimates of standing biomass, with an acceptable time investment.

Leaf Area. During 2000, we experimented with a pin frame (Bonham 1989) and a leaf area meter (LI-COR LAI-2000 plant canopy analyzer; LI-COR Environmental, Lincoln, NE) to estimate leaf area. It would be advantageous to have a measure 
of leaf area that correlates well with biomass. Ideally, if a method correlated well with aboveground biomass, then destructive sampling would be unnecessary. The $r^{2}$ of the regression relationship between the leaf area meter and clipped biomass was 0.64 . The leaf area meter is a very sensitive instrument. In our experience, its accuracy was influenced by sky conditions, time of day, and nearby objects on the ground. The $r^{2}$ of the regression relationship between the pin frame and clipped biomass was only 0.52 . Like the leaf area meter, the pin frame was difficult to use in areas with dense vegetation, where overlapping leaves close to the ground make it difficult to see and record multiple hits. Because of these shortcomings, we discontinued both the pin frame and the leaf area meter.

Percent Green Vegetation. The purpose of collecting percent green information was to quantify the green and senescent vegetation and compare this information with the imagery. Initially, as the 10-point pin frame was used to measure canopy cover within quadrats, each hit was also recorded as green or brown. However, after the pin frame was discontinued, the comparative yield quadrats were used to estimate percent green. In each quadrat that was assigned a comparative yield rank, an estimate of percent green visible to the observer was also noted. The percent green for each quadrat was classified into one of 5 classes, spanning the range of $0 \%-100 \%$. Estimated percent green for the plot was calculated as the mean of the midpoints of estimated green percent for all quadrats.

Plant Height. Plant height information was collected to establish plant volume in conjunction with the line intercept canopy cover. It was also compared to image data for calibration purposes. The heights of 100 individual plants were measured at $0.3-\mathrm{m}$ intervals along $30-\mathrm{m}$ transects. Inflorescences were excluded because their small biomass to height ratio would overestimate plant volume. Measurements were made at each point along the transect where the nearest leaf of the nearest plant touched a vertical meter stick.

Canopy and Ground Cover. Line intercept canopy cover by species was measured to thoroughly characterize the sites, classify the vegetation types, and provide information for evaluating and calibrating imagery data. Line intercept transects were measured at sites during the winter/spring period and/or the end of the summer growing season. There were 3 to 5, 30-m transects per site randomly located within a systematic sampling design. Each $150-\mathrm{m}$ baseline had 1 or 2 transects placed perpendicular to the baseline, at randomly selected distances. One hundred ground cover points were also obtained along each transect. The ground cover categories were: bare ground, litter, gravel (5-20 mm), rock (> $20 \mathrm{~mm})$, plant crown, and microbiotic crust. For both the pin frame and the transect, if litter fell on top of gravel or rock, the point was designated as litter, because that is what the image detects.

Time Investment. A team of 2 experienced people can collect data on up to 5 line transects and up to 100 comparative yield sample quadrats on such a site during 1 full day of field work. Data processing time varies depending on the method of field data collection and the number of sites sampled. During 2001, we used a laptop computer with direct input of data into
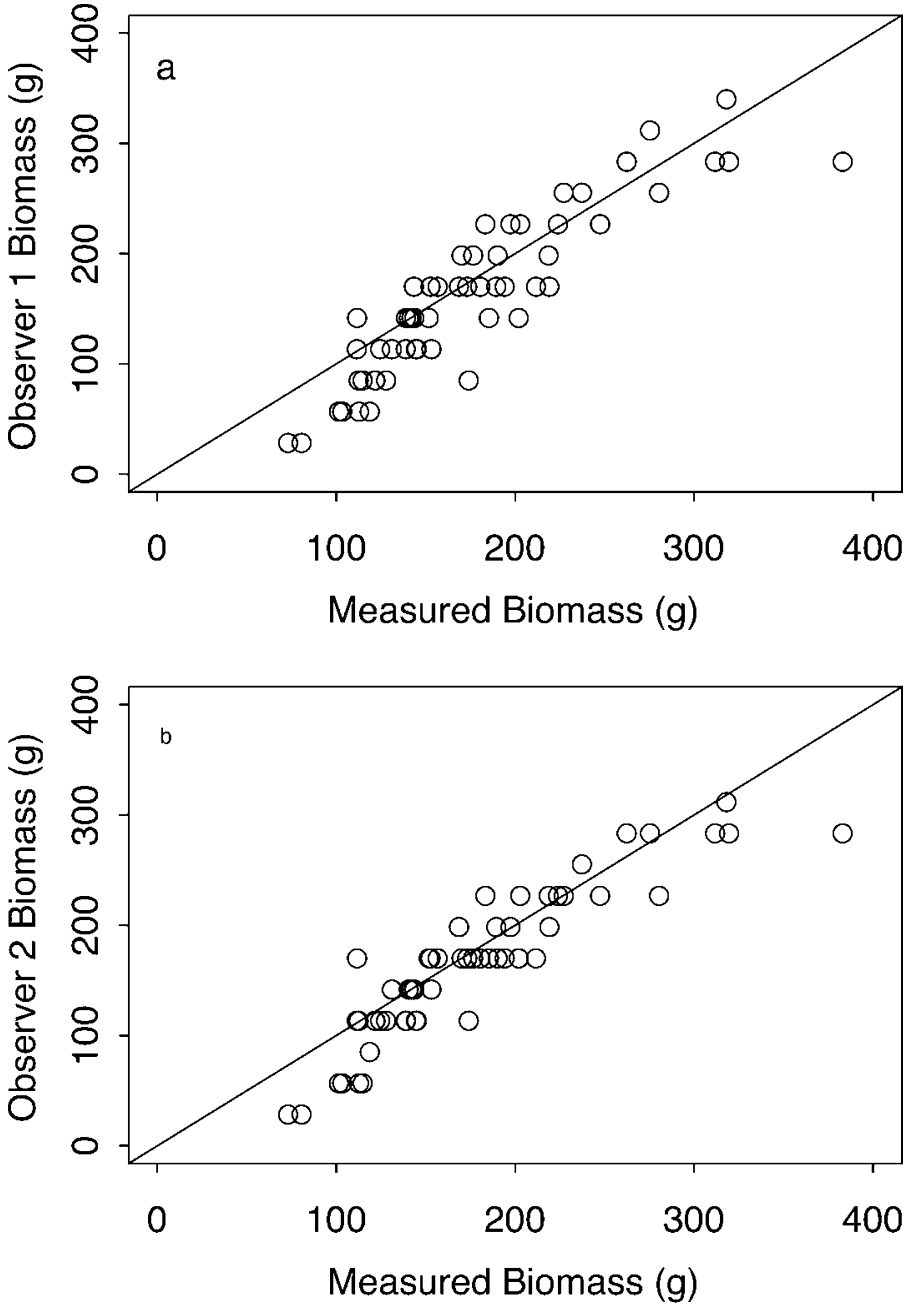

Figure 2. Comparative yield estimates vs. clipped biomass and the oneto-one line for 2 observers.

a Microsoft Access ${ }^{\circledR}$ database. This procedure saved several weeks of office data entry compared to 2000 when hard-copy data sheets were used in the field at 8-10 sites.

Image Processing. Image processing began with Precision Terrain Corrected Landsat images. The images were converted to reflectance using MODTRAN derived coefficients. Whereas band 4 NIR reflectance values were used in the vegetation indices to calculate cover, band 4 was rescaled to 8 bit (0-255) data for ease of use in the band 4 reversal process used in the site height and biomass procedures.

\section{RESULTS}

\section{Volume to Biomass Relation}

As the Landsat sensor integrates the response from the land surface for each pixel, there is a useful concept of the height of the vegetation, assuming that all vegetation has been rearranged so that it completely covers the land surface to a uniform height. This value can be calculated by multiplying the average plant height by the percent cover, and is referred to here as the "site height." A relationship between plant volume and biomass 


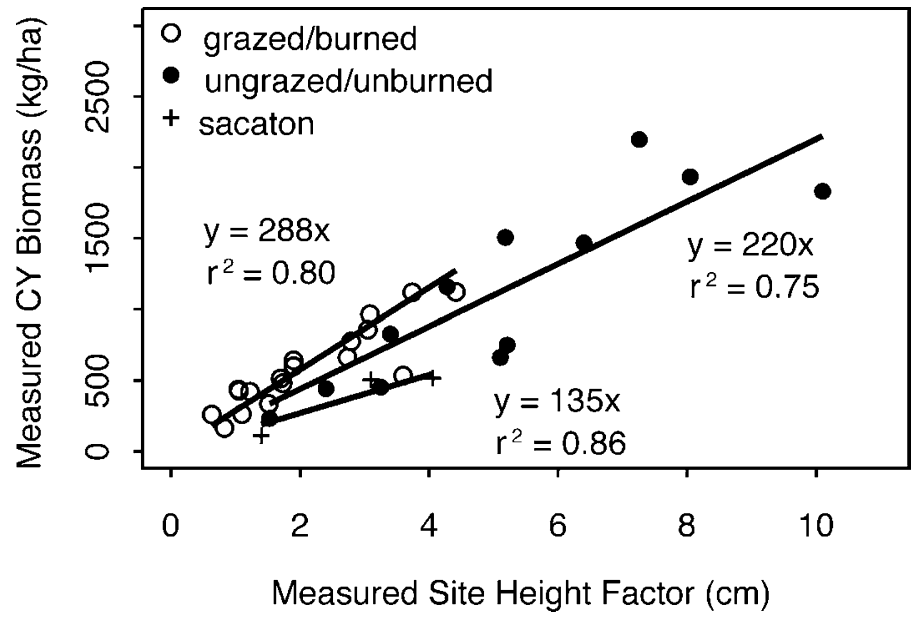

Figure 3. The comparative yield biomass plotted against the site height factor (average plant height $\times$ plant cover on plot) for only those sites where forbs constituted less than $30 \%$ of the biomass.

was established by regressing the average site height against the comparative yield biomass of several southeast Arizona sites with collection dates from September 2000 to June 2004. The results indicated that there was a trend with an $r^{2}$ of 0.65 . The outliers were sites with a large forb component. By selecting 42 observations from Arizona, New Mexico, and Mexico with collection dates from September 2000 to June 2004, with forbs representing no more than $30 \%$ of the vegetation cover, the $r^{2}$ improved to 0.78. Analysis of variance (ANOVA) indicated significant differences between grazed and ungrazed sites $(F=5.05$ and $P=0.01)$. Separating the data points into these 3 categories resulted in $r^{2}$ values of $0.82,0.86$ and 0.75 for grazed sites, upland Sacaton sites, and long-term exclosures labeled ungrazed sites, respectively (Fig. 3).

\section{Algorithm Development}

A number of vegetation indices have been developed as a simple, but practical, approach to estimate vegetation properties (Richardson and Wiegand 1977; Kaufman and Tanre 1992; Myneni and Asrar 1994; Qi et al. 1994). Recent development of vegetation indices includes those that were specific for satellite sensors such as MODIS enhanced vegetation index (EVI; Huete et al. 1996) and MERIS index (MGVI; Gobron et al. 1999). These indices, even though different in formulae, were developed using the contrast between the red and near-infrared reflectance, and therefore are primarily correlated with green vegetative cover, green leaf area index, and total green biomass.

Previous approaches to estimate rangeland biomass have often used the NDVI (Tucker 1979; Hunt and Miyake 2006) or SAVI (Washington-Allen et al. 2006) to predict biomass. One disadvantage is that the indices are only sensitive to green vegetation, with best results when vegetation is most green (Reeves et al. 2006). Unfortunately, vegetation is green during the season when the potential for obstructing cloud cover is greatest. In contrast, our approach is designed to work with senescent grass, when cloud cover is likely to present only minor problems. In addition, estimates of production based on

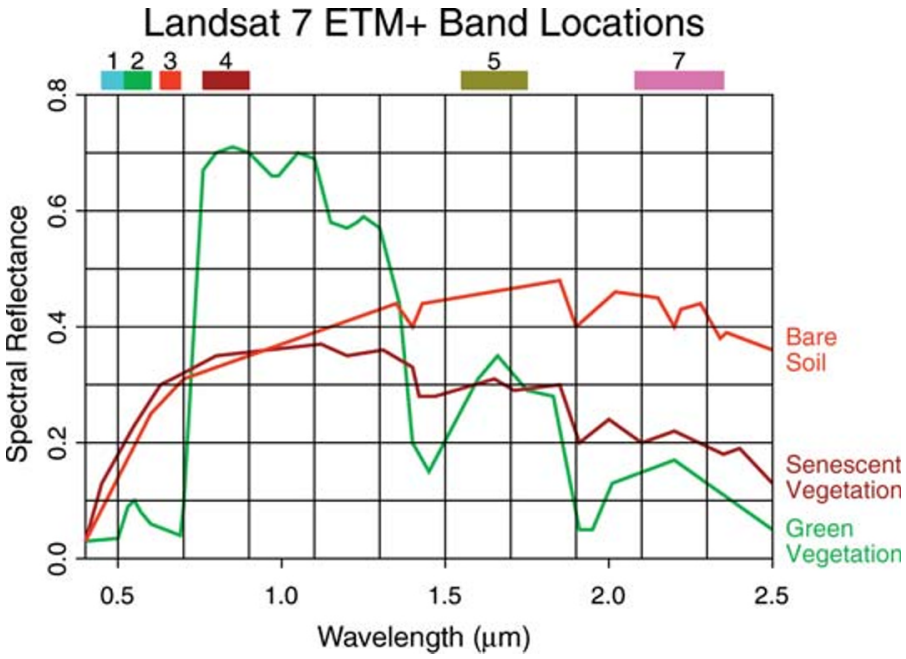

Figure 4. The spectral signatures of both green and senescent vegetation are similar in Landsat 7's band $5(1.55 \mu \mathrm{m}$ to $1.75 \mu \mathrm{m})$.

the difference between biomass estimates made just prior to and following the growing season are more likely to include all growth (less utilization) than pairs of estimates made during the growing season.

\section{Fractional Canopy Cover}

The first task in geospatial product development was to find a way of quantifying the senescent, as well as green, biomass. We accomplished this by using a simple index, the normalized difference senescent vegetation index (NDSVI) derived from the short wave infrared, SWIR $(1.65 \mu \mathrm{m})$ and red $(0.66 \mu \mathrm{m})$ bands, (NDSVI):

$$
N D S V I=\frac{\rho_{\text {band } 5}-\rho_{\text {band } 3}}{\rho_{\text {band } 5}+\rho_{\text {band } 3}}
$$

where $\rho$ is reflectance values in either band 5 (shortwave infrared) or band 3 (red). Considering the fact that the SWIR band is sensitive to water content, it was reasoned that, as vegetation dries, the SWIR band reflectance should increase and therefore the NDSVI would enhance the senescent vegetation. The spectral reflectances of vegetation, both green and senescent, and bare soil, as well as the wavelengths comprising Landsat bands, are shown in Figure 4. The similarity of response of both green and senescent vegetation in Landsat's band 5 can also be seen. Preliminary results with this approach using field spectroradiometer data, ground reconnaissance data, and remotely sensed imagery showed that NDSVI was indeed sensitive to the senescent vegetation, and the results also indicated that NDSVI was sensitive to the green vegetation and, to a lesser extent, the soil. Having the green vegetation quantified with the senescent vegetation was not a problem and, in fact, it simplified the task by eliminating the need for working on green vegetation separately. We did, however, need to find a way to eliminate the soil from the index.

We revised the NDSVI by including a soil adjustment factor in the NDSVI equation as in the SAVI (Huete 1988). This resulted in the Soil Adjusted Total Vegetation Index (SATVI): 


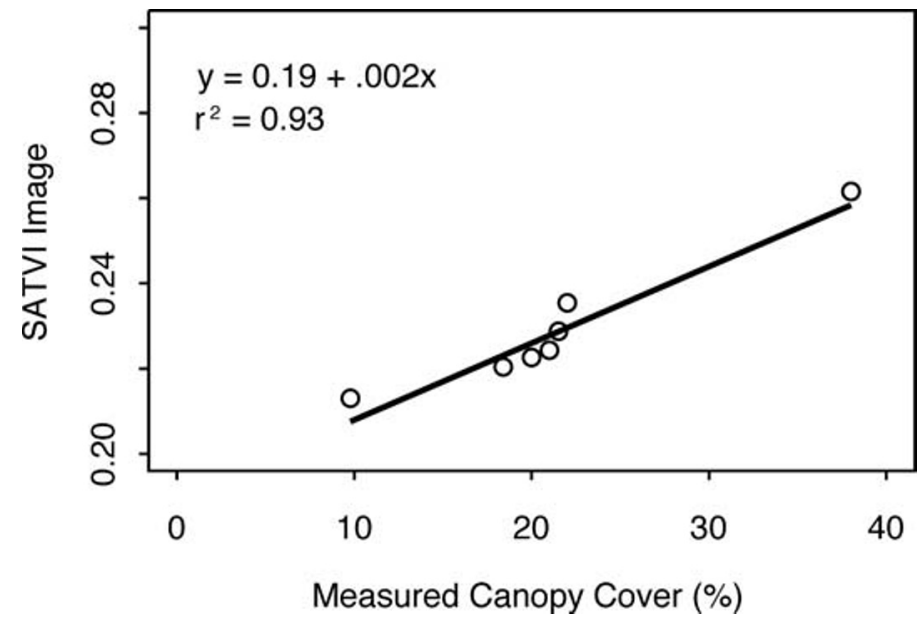

Figure 5. Soil Adjusted Total Vegetation Index (SATVI) compared to measured cover for the Spring 2004 image in southeastern Arizona.

$$
S A T V I=\frac{\rho_{\text {band } 5}-\rho_{\text {band } 3}}{\rho_{\text {band } 5}+\rho_{\text {band } 3}+L}(1+L)-\frac{\rho_{\text {band } 7}}{2}
$$

where $\rho$ is reflectance values in band 5 SWIR (shortwave infrared), band 3 (red) or band 7 SWIR2 (mid infrared). Unlike the commonly used Normalized Difference Vegetation Index (NDVI; Tucker 1979), with the same form as equation 1, with the Near Infrared (NIR) band used in the place of the SWIR band, this new index was found to be sensitive to both green and senescent vegetation, which is needed for rangeland canopy estimates. The $r^{2}$ between the SATVI image and the ground truth canopy cover for the Spring 2004 image was 0.93 (Fig. 5).

The SATVI, unlike NDVI, which as a dynamic range of -1 to 1 in theory, has a practical lower limit of 0.0 , but the upper boundary is undetermined. This is not a problem for our application. In the practical application of this index, all we need to do is to find the endmembers corresponding to the minimum and maximum values of the SATVI and scale it to percent cover (in many cases, we select bare soil, $0.0 \%$ cover, and full canopy, 100\%). Therefore, although the index itself does not have a dynamic range of 0 and 1 , the total fractional vegetative cover will be between $0 \%$ and $100 \%$. Thus, to convert the SATVI to a total vegetation fractional cover (TVFC), we use linear unmixing theory in a vegetation index domain, and derive the following equation for total fractional cover computation:

$$
t v f c=\frac{S A T V I-S A T V I_{\min }}{S A T V I_{\max }-S A T V I_{\min }} 100(\%)
$$

where $\mathrm{SATVI}_{\min }$ and $\mathrm{SATVI}$ max are derived from the image as endmembers, as used in green vegetation fractional cover estimations (Gutman and Ignatov 1998; Maas 1998; Qi et al. 2000).

A canopy cover image is then calculated from the TVFC image, by subtracting the TVFC from areas in the image known to have no cover from the whole image. The resulting image is then stretched so that cover is estimated from TVFC values based on the observed data. Ideally, unmeasured, completely vegetated areas on the image would also be predicted to have $100 \%$ cover with this relationship, but sometimes the cover is

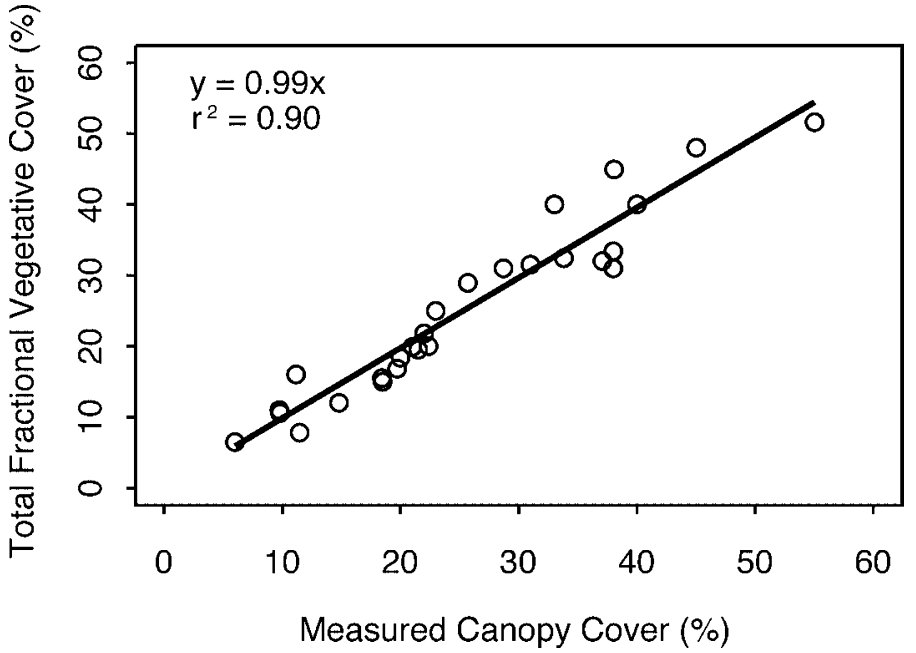

Figure 6. Total fractional vegetative cover (TFVC) estimated from imagery compared to measured cover for all grassland study areas.

overestimated above $80 \%$ canopy. This is not perceived as a problem in semiarid rangelands where herbaceous cover rarely exceeds $50 \%$. Figure 6 compares observed and estimated values of fractional cover for all upland grass study sites, including those with more than $30 \%$ forb cover.

\section{Site Height}

The second task in the algorithm development was to determine the herbaceous vegetation site height. By assuming that the shadows cast by aboveground objects would reduce signal amplitude of reflected data proportionally to those objects' height and extent, we looked for inverse relationships between various bands and band combinations and the ground reconnaissance-derived vegetation height factor. The best relationship was found in the NIR, band 4 .

By converting the NIR to a reversed image (255-NIR), a direct relationship was established between this image and the ground truth derived vegetation site height. The image values plotted against the ground reconnaissance values provide an $r^{2}$ of 0.82 (Fig. 7). Given the NIR data, a site height factor can

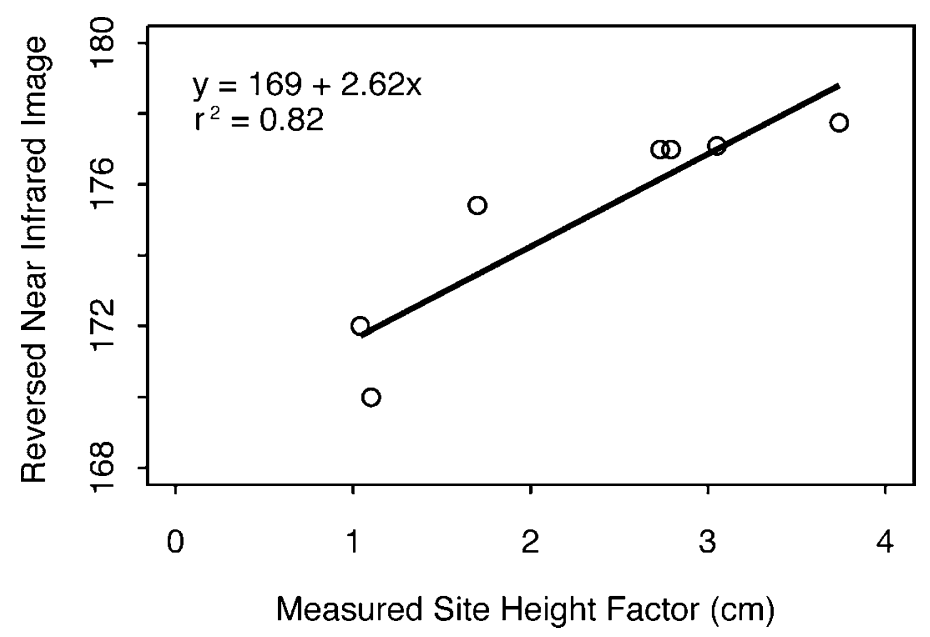

Figure 7. Reflectance scaled to 255 and plotted against measured cover for Spring 2004 image in Arizona. 


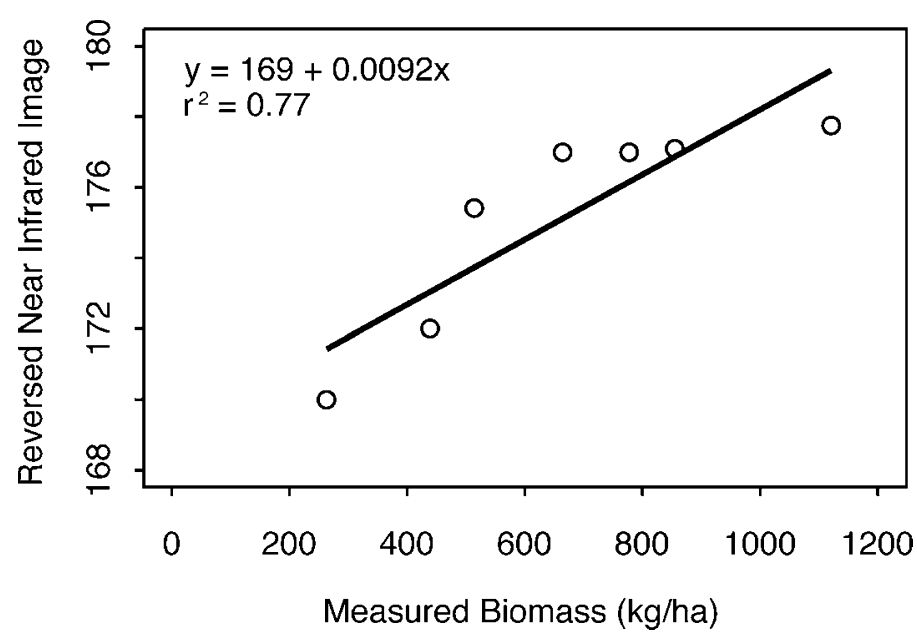

Figure 8. Reflectance scaled to 255 and plotted against measured biomass for Spring 2004 image in Arizona.

then be calculated as $\mathrm{SHF}=([255$-band 4-intercept $] /$ slope $)$ where $\mathrm{SHF}=$ site height factor, and the intercept and slope are from the regression equation in Figure 7. For simplicity, a linear relationship between the Site Height Factor and reversed band 4 values was assumed. This equation is then used to convert the reversed band 4 image to a site height factor image of the entire scene. This image can be further converted to an average vegetation height image by dividing the site height factor image by the fractional cover image.

\section{Biomass}

The final task in the algorithm development was to quantify grass biomass. Because the relationship between the ground truth-derived site height factor and biomass was strong and the relationship between the ground truth site height factor and the reversed NIR image were strong, the next step was to check the reversed NIR image relationship to the ground truth biomass (Fig. 8). The strong relationship between the ground truth and image data was derived from several sites with biomass ranging from less than 300 to more than 1100 $\mathrm{kg} \cdot \mathrm{ha}^{-1}$. By applying the regression from this relationship to the reversed NIR image, a new image was produced with pixel values expressed as $\mathrm{kg} \cdot \mathrm{ha}^{-1}$. Twenty-three upland grassland sites from Arizona, New Mexico, and Chihuahua, Mexico, with collection dates from fall 2000 to spring 2005 were considered. These sites all had forb cover of less than $30 \%$ and combined shrub and tree cover of less than $10 \%$. With these restrictions, and noting the fact that some of the measurements used to develop the regression relationships are also plotted, the estimated biomass values showed a strong relationship with an $r^{2}$ of 0.96 (Fig. 9).

\section{DISCUSSION}

Cover, height, and biomass images are the end product of the processing described above. Example images from the spring of 2004 for southeastern Arizona can be seen in Figures 10-12. The outline of several stakeholder properties are shown: the Bureau of Land Management's Empire Ranch is in the upper left, Audubon's Appleton-Whittell Ranch is in the lower left,

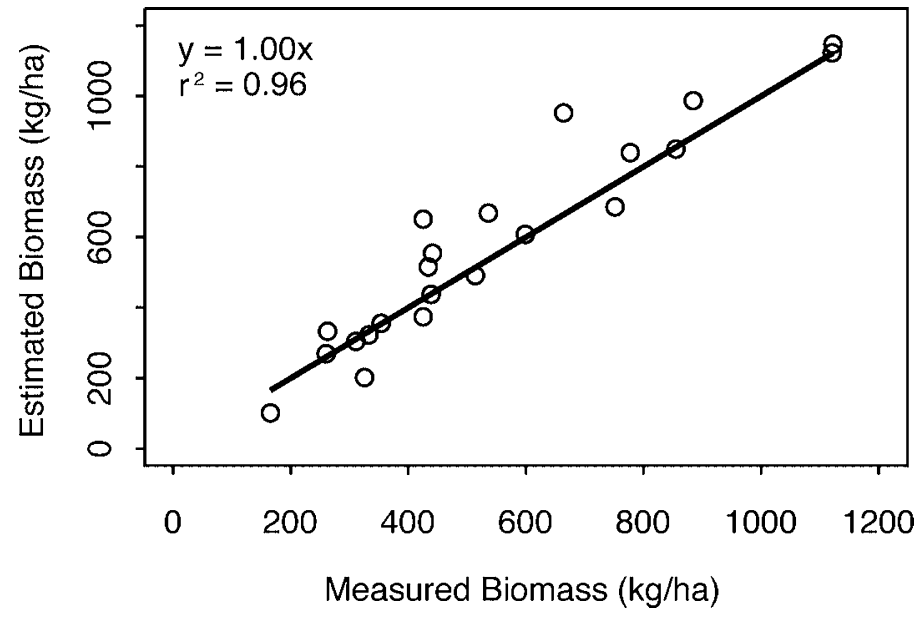

Figure 9. Plot of estimated (from image) vs. measured biomass for all plots with less than $30 \%$ forb biomass.

and Fort Huachuca is in the lower center. Several mountain ranges and the San Pedro River flowing north are clearly visible. The outline of the Ryan Fire of 2002 can be seen traversing the Appleton-Whittell Research Ranch and the northwest corner of Fort Huachuca. The 2 features with very low cover, height, and biomass on Fort Huachuca are the airport and cantonment areas. Low cover is also apparent to the south and east of Fort Huachuca in the town of Sierra Vista, and as a spot to the north of the Fort inside a clearly visible landscape feature (a terrace) where a landfill is located. The same features are apparent in the height and biomass images.

Figures 10-12 do not portray the detail available when digitally manipulating the images. Once the images have been produced, the resulting layers can be manipulated digitally to allow zooming; classification into areas of low, normal, and high cover; and operations such as summing of biomass within a polygon to estimate forage in a pasture, integration with GIS data to show ownership or landmarks such as road networks, and other operations capable of application with digital data.

A limiting factor in the application of this information is the fact that other geographic layers are needed as well. Because the algorithm was developed for grasslands, misleading information will be provided on areas not dominated by grass unless those areas are masked. Similarly, the algorithm will not correctly estimate biomass on subirrigated Sacaton bottoms, although preliminary efforts indicate that it would be possible to develop a separate site height to biomass relationship for Sacaton bottoms. In the information presented to stakeholders, areas under evergreen vegetation and very high mesquite cover were masked, where evergreen vegetation was estimated using NDVI images in the winter, and mesquite cover estimated as the increase in green cover from the evergreen vegetation after mesquite greenup in a dry year. Vegetation under mesquite trees is not visible to the sensor, so if it is significant, knowledge of the cover, height, and biomass under trees would have to be used to apply those estimates. As previously noted, data collection should be avoided when forb cover is high. As the forb cover is ephemeral, one can delay field data collection to wait for desiccation of the forb component, although that might affect the timeliness of the end product. 

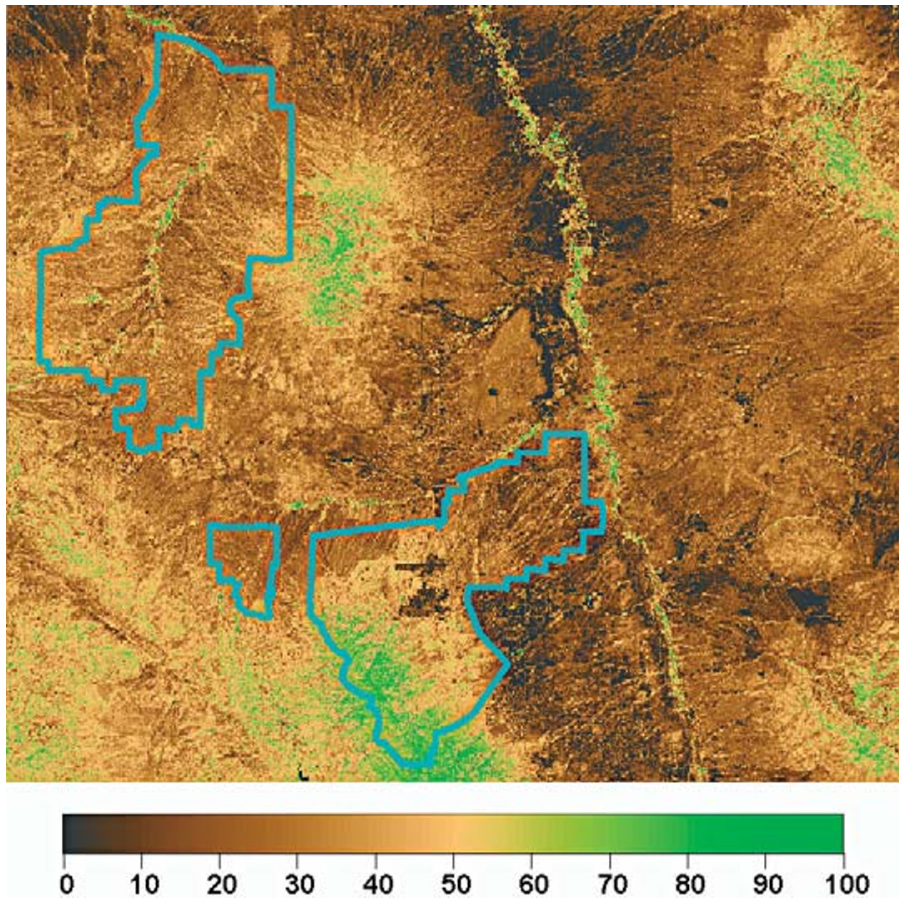

Figure 10. Canopy cover (\%) image for a part of southeastern Arizona (Landsat 5, Path 35, Row 38, 11 June 2004).

There are three main contributions of this research. The first is the development of a ground data collection approach compatible with the $30-\mathrm{m}$ pixel size of Landsat imagery for estimation of cover, height, and biomass on grasslands. Second, the SATVI is a new vegetation index developed for use during the dry season to quantify the cover of herbaceous vegetation. Lastly, grass biomass can be estimated using an empirical equation related to NIR. These contributions appear to work well in a number of grassland types common in the southwest.

\section{Validation}

The fractional cover algorithm was validated in previous research (Maas 1998; Qi et al. 2000; Zeng et al. 2000). Additional validation was undertaken for the 3 main outputs of this study: fractional cover, site height, and biomass. Seventeen points with observed data independent of those used to develop the empirical relationships for estimation were selected. All 17 points were used to validate cover, but only 9 points were available for validation of height and biomass, because some points could not be used due to high forb production, and more points are required to develop the empirical relationships for height and biomass than for cover. The validation data are all from southeastern Arizona, on images from fall 2001 and late spring of 2004 and 2005.

Plots comparing observed and estimated values for all 3 variables are shown in Figure 13 and validation statistics are shown in Table 2. Although the total number of field observations was limited in this study, the estimated values are close to the observed values and are highly correlated to them, with $r^{2}$ values of $0.90,0.92$, and 0.88 and Nash Sutcliffe model efficiency values of $0.78,0.70$, and 0.77 for the fractional cover, site height, and biomass, respectively. Paired $t$-tests

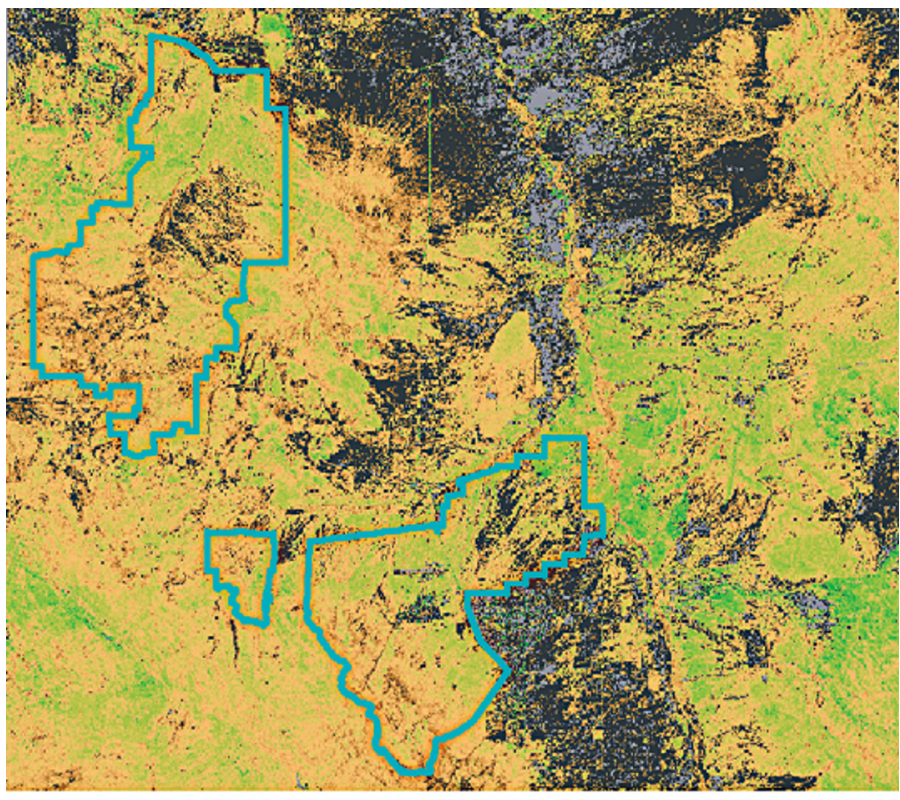

$\begin{array}{lllllllllllllllllllll}125 & 5 & 7.5 & 10 & 12.5 & 15 & 17.5 & 20 & 22.5 & 25 & 27.5 & 30 & 32.5 & 35 & 37.5 & 40 & 42.5 & 45 & 47.5 & 50\end{array}$

Figure 11. Height $(\mathrm{cm})$ image for a part of southeastern Arizona (Landsat 5, Path 35, Row 38, 11 June 2004).

for all three variables did not result in rejecting the null hypothesis that the mean of the differences between observed and estimated values was equal to 0 , although the site height estimate was close to being rejected. Even though the number of validation observations was limited for this study, the agreement between field observations and satellite estimates agreed well at most sites.

\section{MANAGEMENT IMPLICATIONS}

The most likely immediate beneficiaries of the approach presented here are public land managers rather than individual ranchers. Public land managers are responsible for increasingly large areas and can benefit from a distributed and quantified estimate of grassland cover, height, and biomass. In areas where all grass biomass can be considered forage, seasonal stocking rates could be calculated easily. The greatest benefit however, is probably the ability to identify and focus on problem areas. Other benefits include the abilities to extrapolate from limited ground monitoring locations with increased confidence, to review inaccessible areas, and to document change across the landscape over time. With additional work, the cover, height, and biomass layers could be converted to information on fine fuel loads, habitat values, and parameters for hydrologic and erosion models.

Ranchers on public lands could benefit from the cover, height, and biomass estimates, although improved documentation could lead to either increased or decreased stocking rates, depending on conditions. A potential benefit for ranchers is in cases where there are differences of opinion with the public land manager about how much forage is available. The satellite-derived information provides an objective estimate that is not dependent on the judgment of either the rancher or the individual public land manager. 


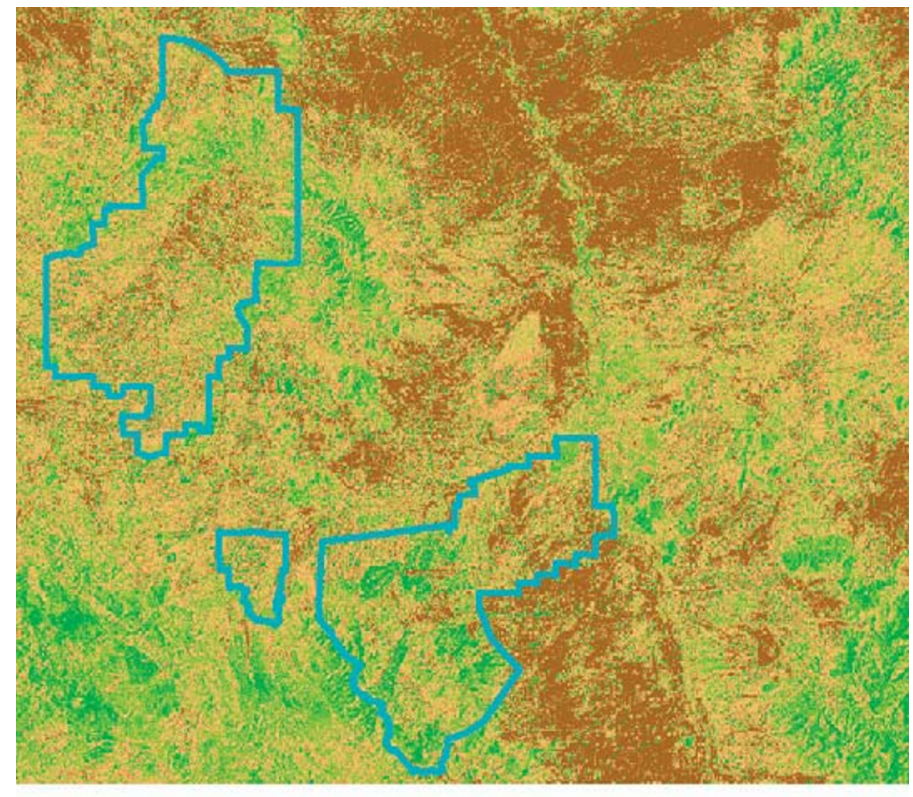

$\begin{array}{llllllllll}125 & 363 & 601 & 839 & 1077 & 1315 & 1553 & 1791 & 2029 & 2268\end{array}$

Figure 12. Biomass $\left(\mathrm{kg} \cdot \mathrm{ha}^{-1}\right)$ image for a part of southeastern Arizona (Landsat 5, Path 35, Row 38, 11 June 2004).
Table 2. Statistical comparison of estimated values of the fractional cover, site height, and biomass and independent ground measurements.

\begin{tabular}{lccc}
\hline & Fractional cover & Site height & Biomass \\
\hline Pearson Correlation & 0.90 & 0.92 & 0.88 \\
Nash Sutcliffe & 0.78 & 0.70 & 0.77 \\
$r$ squared & 0.80 & 0.85 & 0.77 \\
Degrees of freedom & 16 & 8 & 8 \\
$P$ value & 0.315 & 0.057 & 0.972 \\
Mean difference & 1.702 & -0.0438 & 1.667 \\
95\% confidence Interval & -1.77 to 5.18 & -0.89 to 0.02 & -102.60 to 105.93 \\
Significantly different? & No & No & No \\
\hline
\end{tabular}

Limitations of the approach presented here include the fact that the height and biomass products are limited to grassland that is not dominated by forbs at the time of the image. Additional research is needed to extend the approach to mixed grass-shrub and grass-tree sites that represent a large portion of rangelands.

A further limitation is the requirement for field data collection to calibrate each Landsat image. This is a strength in that image processing serves to extrapolate from points of known quantities across an image. However, the fieldwork is time-consuming and therefore expensive. The fieldwork and remote sensing effort imply high fixed costs to prepare an image, but low variable costs to extract data for additional

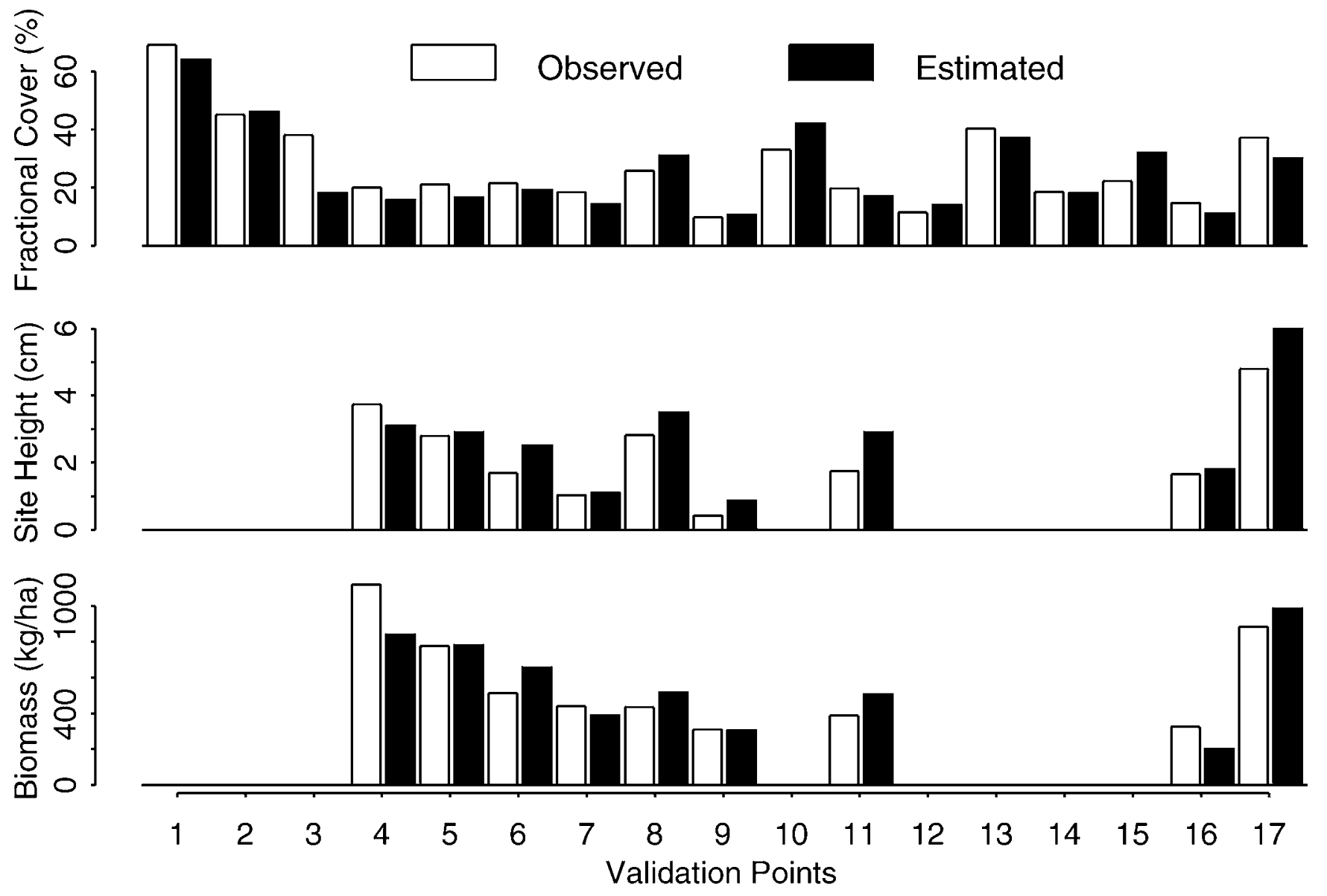

Figure 13. Measured vs. estimated cover, height, and biomass for validation sites. 
areas within a processed image. To support the required data collection for widespread application, the products will have to be sold commercially. If multiple areas within an image can be processed and sold, the high fixed costs can be spread across a large area, reducing the costs to all users. Although pricing would be highly dependent on the proportion of an image sold, if several public land management units were to buy coverage, the cost of producing one-time cover, height, and biomass images would fall to around $\$ 0.01$ per acre.

Almost 2 decades have passed since Tueller (1989) concluded "The future of rangeland remote sensing is a bit hazy. It is fair to conclude that research ... will lead us closer and closer to an ability to use remote sensing to quickly and efficiently measure many parameters of interest." Today, we have the data needed from satellites and advanced computational capability. Real time operational monitoring of several key grassland variables from remotely sensed imagery, as a complement to monitoring done on the ground, is possible. The operational use of satellite images for rangeland management is within sight.

\section{ACKNOWLEDGMENTS}

We gratefully acknowledge the assistance and encouragement of the Audubon's Appleton-Whittell Research Ranch in Elgin, Arizona; the Bureau of Land Management; Forest Service; Fort Huachuca; Arizona State Land Department; and a number of private ranches and cooperators. Special thanks to Chandra Holifield and Jared Buono at USDA-ARS SWRC, Tucson, Arizona, and Osman Wallace at Michigan State University, East Lansing, Michigan. We also thank Dr M. Keith Owens, Dr E. Ray Hunt, and several anonymous reviewers for their helpful comments in revising the manuscript.

\section{LITERATURE CITED}

Bonham, C. D. 1989. Measurements for terrestrial vegetation. New York, NY: John Wiley and Sons. $352 \mathrm{p}$.

BreCKenfeld, D. J. 1993. Soil survey of Walnut Gulch Experimental Watershed, Arizona. Tucson, AZ: USDA-SCS and USDA-ARS in cooperation with Arizona Agricultural Experiment Station. $136 p$.

Brown, D. E., And C. H. Lowe. 1994. Biotic communities: southwestern United States and northwestern Mexico. Salt Lake City, UT: University of Utah Press. $342 \mathrm{p}$.

Bureau of Land Management. 1996. Sampling vegetation attributes. Interagency technical reference BLM/RS/ST-96/002+1730. Denver, CO: BLM National Applied Resources Sciences Center. p. 112-121.

Despain, D. W., AND E. L. Smith. 1997. The comparative yield method for estimating range production, In: G. B. Ruyle [ED.]. Some methods for monitoring rangelands. Tucson, AZ: University of Arizona Cooperative Extension Report 9043. p. 49-61.

Galt, H. D., B. Theurer, and S. C. Martin. 1982. Botanical composition of steer diets on mesquite and mesquite-free desert grassland. Journal of Range Management 35:320-325.

Gobron, N., B. Pinty, M. M. Verstraete, and Y. Govaerts. 1999. The MeRIS Global Vegetation Index (MGVI): description and preliminary application. International Journal of Remote Sensing 20:1917-1927.

Gutman, G., And A. Ignatov. 1998. The derivation of the green vegetation fraction from NOAA/AVHRR data for use in numerical weather prediction models. International Journal of Remote Sensing 19:1533-1543.

Holechek, J. L., R. D. Pieper, and C. H. Herbel. 1989. Range management principles and practices. Englewood Cliffs, NJ: Prentice Hall. 501 p.

Huete, A. R. 1988. A soil-adjusted vegetation index (SAVI). Remote Sensing of the Environment 25:295-309.

Huete, A. R., C. Justice, and W. van Leeuwen. 1996. MODIS Vegetation index (MOD 13), EOS MODIS algorithm-theoretical basis document. Greenbelt, MD: NASA Goddard Space Flight Center. $115 \mathrm{p}$.

Hunt, E. R., JR., J. H. Everitt, J. C. Ritchie, M. S. Moran, D. T. Booth, G. L. Anderson, P. E. Clark, and M. S. Seyfried. 2003. Applications and research using remote sensing for rangeland management. Photogrammetric Engineering and Remote Sensing 60:675-693.

Hunt, E. R., JR., And B. A. Miyake. 2006. Comparison of stocking rates from remote sensing and geospatial data. Rangeland Ecology and Management 59:11-18.

Kaufman, Y. J., and D. TanRe. 1992. Atmospherically resistant vegetation index (ARVI) for EOS-MODIS. IEEE Transactions on Geoscience and Remote Sensing 30:261-270.

MAAS, S. 1998. Estimating cotton canopy ground cover from remotely sensed scene reflectance. Agronomy Journal 90:384-388.

Myneni, R. B., and G. Asrar. 1994. Atmospheric effects and spectral vegetation indices. Remote Sensing of the Environment 47:390-402.

National Research Council. 1994. Rangeland health: new methods to classify, inventory, and monitor rangelands. Washington, DC: National Academy Press. $180 \mathrm{p}$.

Pickup, G., G. N. Bastin, and V. H. Chewings. 1994. Remote-sensing-based condition assessment for nonequilibrium rangelands under large-scale commercial grazing. Ecological Applications 4:497-517.

Qı, J., A. Chehbouni, A. R. Huete, Y. H. KerR, and S. Sorooshian. 1994. A modified soil adjusted vegetation index. Remote Sensing of the Environment 48: 119-126.

Qı, J., R. C. Marsett, M. S. Moran, D. C. Goodrich, P. Hellman, Y. H. Kerr, G. Dedieu, A. Chenbouni, and X. X. Zhang. 2000. Spatial and temporal dynamics of vegetation in the San Pedro River Basin Area. Agricultural and Forest Meteorology 105:55-68.

ReEVES, M. C., J. C. WinsLow, And S. W. Running. 2001. Mapping weekly rangeland vegetation productivity using MODIS algorithms. Journal of Range Management 54:A90-A105.

Reeves, M. C., M. ZhaO, And S. W. Running. 2006. Applying improved estimates of MODIS productivity to characterize grassland vegetation dynamics. Rangeland Ecology and Management 59:1-10.

Richardson, A. J., AND C. L. Wiegand. 1977. Distinguishing vegetation from soil background information. Photogrammetric Engineering and Remote Sensing 43:1541-1552.

TUCKER, C. J. 1979. Red and photographic infrared linear combinations for monitoring vegetation. Remote Sensing of the Environment 8:127-150.

TuelleR, P. T. 1989. Remote sensing technology for rangeland management applications. Journal of Range Management 42(6):442-453.

Tueller, P. T. 2001. Remote sensing of range production and utilization. Journal of Range Management 54:A77-A89.

USDA-NRCS. 2005. The national cooperative soil survey web soil survey, version 1.0. Available at: http://websoilsurvey.nrcs.usda.gov/app/. Accessed 26 October 2005.

Washington-Allen, R. A., N. E. West, R. D. Ramsey, and R. A. Efroymson. 2006. A protocol for retrospective remote sensing-based ecological monitoring of rangelands. Rangeland Ecology and Management 59:19-29.

Zeng, X., R. E. Dickinson, A. Walker, M. Shaikh, R. S. DeFries, and J. Q. 2000. Derivation and evaluation of global $1-\mathrm{km}$ fractional vegetation cover data for land modeling. Journal of Applied Meteorology 39(6):826-839. 